\title{
Low dose and subchronic Aroclor 1254 induced histopathological changes in mice kidney
}

\author{
Jalpa Raja, Shweta Pathak, Rahul Kundu* \\ Department of Biosciences, Saurashtra University, Rajkot, Gujarat, India
}

\begin{tabular}{l}
\hline ARTICLE INFO \\
\hline Article history: \\
Received on: September 29, 2018 \\
Accepted on: December 15, 2018 \\
Available online: April 05, 2019
\end{tabular}

Key words:

Polychlorinated biphenyls, Aroclor 1254,

In vivo toxicity,

Histopathology,

Kidney,

Mice

\begin{abstract}
Present communication reports the low dose and subchronic duration-dependent histopathological changes after exposure to Aroclor 1254 in the kidney tissue of Swiss albino mice. Polychlorinated biphenyls (PCBs) like Aroclor 1254 congeners accumulate in tissues rich in lipids and remain inside for a long time, affecting the functionality of the cells in direct and indirect ways. The most commonly observed effects were skin ailments such as chloracne, rashes, and effects on kidney functions. Animal studies indicated that PCBs could affect the functionality of the kidney, thyroid, immune, and endocrine systems. Separate groups of mice were subjected to a daily oral dose of $0.1 \mathrm{mg} / \mathrm{kg}$ body weight $(\mathrm{BW}) /$ day and $1 \mathrm{mg} / \mathrm{kg} \mathrm{BW} /$ day Aroclor 1254, dissolved in corn oil, for four subacute exposure durations (7, 14, 21, and 28 days). Control groups were received only the corn oil (vehicle). Results revealed mainly exposure duration-dependent histopathological lesions such as dilation of the tubular cells, fragmentation of cytoplasm and loss of nuclear materials, formation of large vacuoles inside the cells, and necrosis even at very low doses of Aroclor intoxication. The present study reports predominantly exposure duration-dependent histopathological effects of Aroclor 1254 in the kidney tissue of mice. The study suggested that the subacute exposure to low doses of Aroclor 1254 could cause significant irreparable structural deformities in the renal cells of the kidney tissue. Results also showed that renal tubular cells were more affected showing severe necrosis.
\end{abstract}

\section{INTRODUCTION}

Congeners of polychlorinated biphenyls (PCBs), Aroclor 1254 usually have four digit numbers. Among these four letters, the first two digits refer to the number of carbon atoms attached to the biphenyl ring and the last two digits indicate the percentage of chlorine atoms. PCBs were manufactured and used commercially in dielectric fluids of the transformer, capacitor, etc. [1]. PCB congeners are present in the environment and are very harmful to the living biota. These toxicants reach to the human through direct exposure or food chain [2]. The primary route of PCBs exposure is through ingestion of contaminated food, water, and air. Environmental toxicant mechanisms impart toxicity include the formation of alteration in cellular component and free radicals [3]. Oral administration of acute toxicity effects was reported in the liver, kidney, and central nervous system of the exposed animals [4]. Previous studies have indicated that PCBs are likely to accumulate in tissues with high concentrations of lipids and can remain inside for a considerably long time [2]. The tissues with the highest PCB concentrations are skin, blood, brain, liver, kidney, and lungs. Due to the complex structure and number of different

*Corresponding Author

Dr. Rahul Kundu, Department of Biosciences, Saurashtra University,

Rajkot - 360005, Gujarat, India.

Email: rskundu@sauuni.ernet.in congeners, PCBs can undergo a variety of metabolic reactions [1]. The rate of metabolism is generally lower for the more highly chlorinated congeners excrete in feces and urine [3]. It was earlier reported that few derived metabolites might be more harmful than the unchanged congener having half-lives in the body ranged from 2.6 to 8 years [1-3]. The most commonly observed effects in the people exposed to relatively high concentrations of PCBs are skin ailments such as chloracne, rashes, and effects on kidney functions. Effects of PCBs were found to be more severe in alcoholic people where the kidney functions were already compromised [4]. Studies in animals indicated that exposure to PCBs could affect the kidney, thyroid, immune, and endocrine systems [4]. In animals, PCBs have been shown to reduce conception as well as birth rates. Pregnant women exposed to large amounts of PCBs were found to have children with lower birth weight, irregular development of the immune system, and abnormal behavior [5]. Nursing infants are reported to be at higher risk depending on the exposure levels due to the presence of PCBs in breast milk [4]. Kidney being the main excretory organ comes into direct contact of the toxicants present in the blood and thus shows high rate of toxicity related functional alterations [5]. Bruckner et al. [6] reported marked histological changes in the kidney of Aroclor 1242 exposed rats. Earlier, it was reported that high dose of PCB exposure caused increased kidney weight, lesions of hydropic degeneration of convoluted tubules, and tubular dilatation [7-9]. Going through the literature, it was evident that fewer reports have been available on 
the histological and cytological effects of Aroclor congeners on the mammalian systems. The present study was, thus, aimed to evaluate the histopathological toxic effects of low dose and subacute exposure to Aroclor 1254 to the kidney tissue of male Swiss albino mice.

\section{MATERIALS AND METHODS}

\subsection{Experimental Animal Model and Ethics}

Healthy 3-4-month-old-male Swiss albino mice with the body weight of about $30-40 \mathrm{~g}$ were taken for the experimental purposes after acclimatization for a period of 2-3 days before the experiment. The animals were grouped and kept under standard conditions (CPCSEA, Government of India). The experiments were conducted according to the ethical norms approved by the CPCSEA (No. 757/PO/Re/S/03// CPCSEA for Research for Education purpose on small animals, dated 24-04-2017). Animals were provided with approved commercial rodent diet and deionized water ad libitum.

\subsection{Toxicant and Other Chemicals}

Aroclor 1254, PCB (CAS No. 11097-69-1), was procured from Sigma Chemical Company Inc. All other chemicals used in this study were of analytical grade and procured from reputed chemical companies of India.

\subsection{Experimental Design}

In this study, groups of male Swiss albino mice, having same age and weight, were exposed to low sublethal doses of Aroclor 1254 (0.1 and $1 \mathrm{mg} / \mathrm{kg}$ body weight (BW)/day), for four exposure durations $(7,14$, 21, and 28 days). Each group contained a minimum of six animals and similar, but separate control groups were also formed. Toxicity was imposed in the designated groups of mice by oral administration of Aroclor 1254 in two different doses ( 0.1 and $1 \mathrm{mg} / \mathrm{kg}$ BW/day) dissolved in corn oil (vehicle) for four different exposure durations of $7,14,21$, and 28 days. Animals in control groups were given only corn oil. Each experiment was repeated at least 3 times.

\subsection{Histopathological Studies}

After the exposure, kidney tissue was removed, quickly cleaned, dehydrated in graded series of alcohol, and embedded in paraffin wax [10]. Sections of $10 \mu \mathrm{m}$ thick were cut by rotary microtome and stained by hematoxylin and eosin. Properly stained sections were examined for histopathological changes under different magnification using Carl-Zeiss Axioscope 2 compound microscope. Photomicrographs were taken with the help of color vision camera (DONPISHA XC-003) fitted in the microscope using Carl-Zeiss Axiovision 3.1 image analysis software.

\section{RESULTS}

The results of the present study showed predominant exposure duration-dependent histopathological lesions in the kidney tissue of mice. No histopathological lesions, whatever, were observed in the kidney tissue of the control animals that received only corn oil (vehicle). Fewer histopathological lesions in the kidney tissue were observed in the low dose $(0.1 \mathrm{mg} / \mathrm{kg} / \mathrm{BW} /$ day $)$ compared to the control after exposed for 7 days. In this case, slight reductions in the shape and size of the tubular cells were noticed [Figure 1]. However, after 14 days of exposure, the tubular cells showed marked variations in the shape and size [Figure 1]. After longer exposure durations (21 days), cytoplasmic fragmentation in the tubular cells was evident, and after

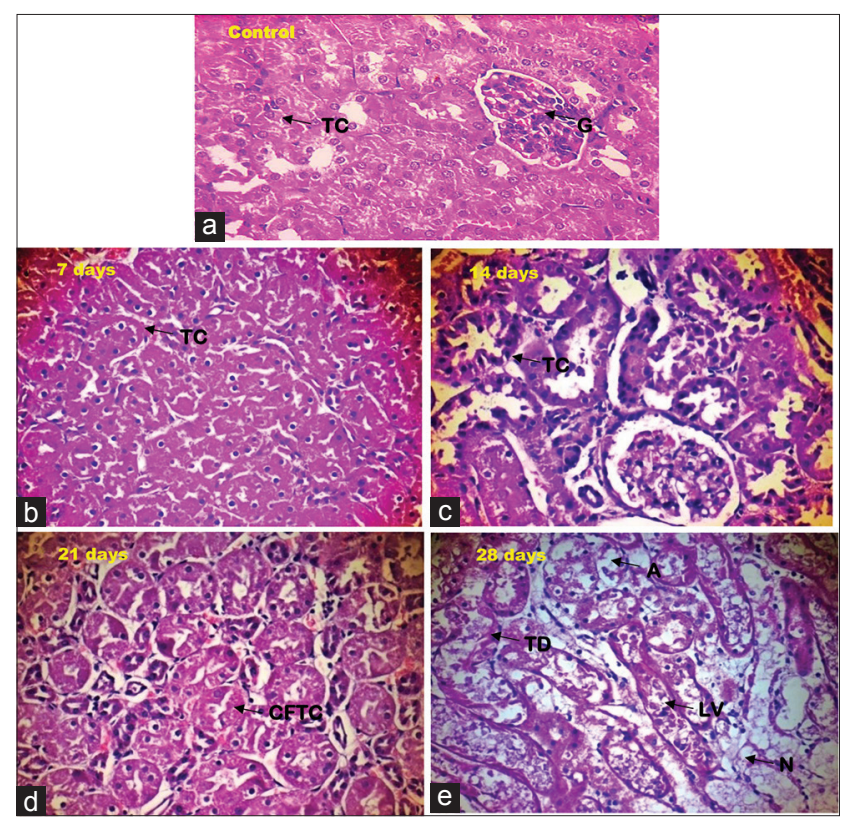

Figure 1: Photomicrographs $(\times 100)$ showed the histopathological alterations in the kidney of mice after the exposure of $0.1 \mathrm{mg} / \mathrm{kg} /$ day dose of Aroclor 1254 for 7, 14, 21, and 28 days as compared to the control. (a) Control: Normal kidney with tubule cells - TC, Glomerulus - G.(b) 7 days: Mild disturbances in the shape and size of tubule cells - TC. (c) 14 days: Variations in shape and size of more number of the tubule cells - TC. (d) 21 days: Cytoplasmic fragmentation in tubule cells - CFTC. (e) 28 days: Maximum tubular dilation - TD, atrophy - A, necrosis - N, formation of large vacuoles - LV

28 days of exposure, maximum tubular dilation and necrosis were observed [Figure 1]. Large vacuoles (LVs) were formed inside the cells. On the other hand, in the higher dose ( $1 \mathrm{mg} / \mathrm{kg} \mathrm{BW} /$ day $)$ exposed after 7 days marked variations in the shape and size of the tubule cells (TCs) were noticed. Fragmentation of cytoplasm and loss of nuclear materials were also observed in few tubular cells [Figure 2]. More instances of these lesions, however, were observed after 14 days of exposure. Fragmentation of nuclear materials in the tubular cells was also evident [Figure 2]. However, various cells of the exposed kidney tissue after 21 days exposure in the high dose (1 mg/kg BW/day) showed marked changes. Cytoplasmic fragmentation and vacuolization were observed in more TCs [Figure 2]. After the longest experiment duration (28 days), the kidney tissue showed the highest degree of cellular destruction. More number of the tubular cells were dilated and disfigured. Vacuolization and nuclear fragmentation of the tubular cells were evident in most of the tubular cells [Figure 2]. In both the doses, most severe effects were observed after longest exposure duration, which were marked by the formation of a large, centrally located void space due to cytoplasmic degradation and necrosis in most of the tubular cells [Figures 1 and 2].

\section{DISCUSSION}

In the present study, the main histopathological findings were the marked dilation of the Bowman's capsule and tubular cells, fragmentation of cytoplasm and loss of nuclear materials, deformation of the glomerular structures, formation of large vacuoles inside the cells, necrosis, etc., at different stages of Aroclor intoxication. Most severe histopathological lesions such as formation of a large, centrally located vacuole, cytoplasmic degradation, and necrosis in most of the 


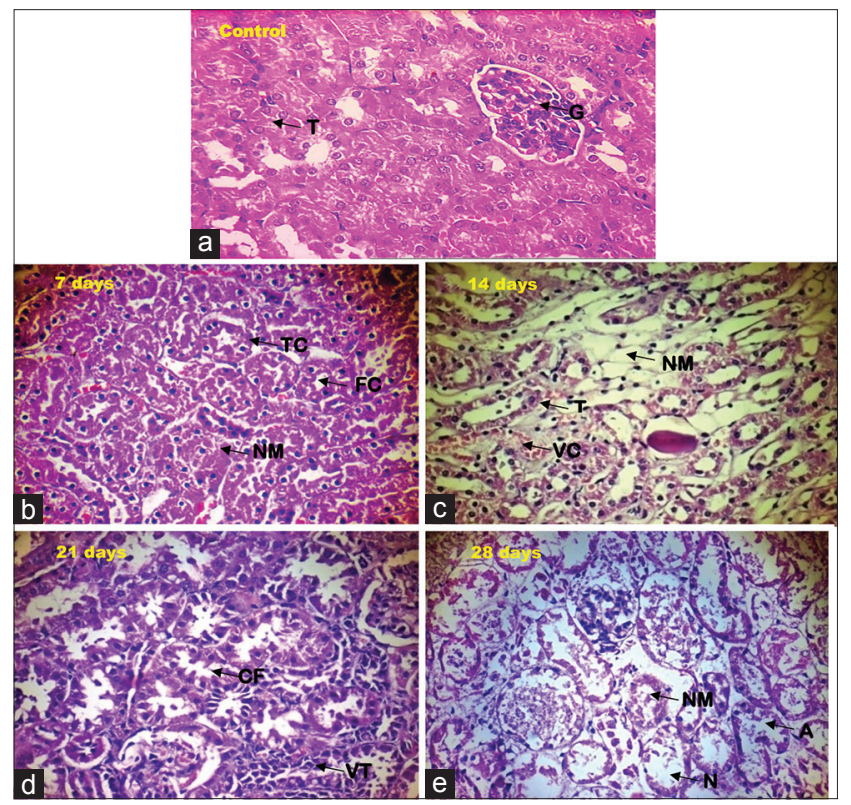

Figure 2: Photomicrographs $(\times 100)$ showed the histopathological alterations in the kidney of mice after the exposure of $1 \mathrm{mg} / \mathrm{kg} /$ day dose of Aroclor 1254 for 7, 14, 21, and 28 days as compared to the control. (a) Control: Normal kidney with tubule cells - TC, glomerulus - G. (b) 7 days: Variation in shape and size of TC, fragmentation of cytoplasm - FC, loss of nuclear material - NM. (c) 14 days: Variations in shape and size of TC, vascular congestion - VC, fragmentation of nuclear material - NM. (d) 21 days: Cytoplasmic fragmentation - CF, vacuolization of tubules cell - VT. (e) 28 days: Atrophy - A, tubules necrosis - N, fragmentation of nuclear material - NM

Bowman's capsule, and the tubular cells were developed after longest exposure duration in both the doses. Apparently, the longer exposure durations caused significantly higher degree of renal lesions in the exposed animals. This type of glomerular pathogenesis was probably due to interferences in the immune complexes, which increases podocyte proliferative changes in the glomerulus [11]. These kinds of renal lesions were reported to be associated with a direct toxicity of lipophilic PCB at the ultrafiltration site [12]. In the lower doses, the onset of more severe effects like .glomerular basement membrane thickening (GBMT) was suggested a direct effect of lipophilic Aroclor 1254 into the plasma membrane of these cells [13]. The observed dilation of glomerular cells and associated necrosis was possibly exhibited by both direct and indirect toxicity of Aroclor 1254 [14]. The structural damage in the tubular cells observed after 28 days of highdose exposure was possibly by the indirect toxicity of Aroclor 1254 to these cells [15]. The vacuolization and fragmentation of the nuclear materials were also indicative of severe oxidative reactions through indirect way $[16,17]$. It was earlier reported that few of the observed pathogenesis could be mediated through the Aroclor 1254 induced immunosuppression [18-20]. The dilations of the glomerular capillaries and mesangial deposits observed after longer exposure durations were possibly due to the effects of highly reactive Aroclor 1254 [18]. However, most of the other observed renal lesions could be due to direct mechanisms of the Aroclor 1254 through the lysosomal way and were associated with renal failure in the exposed mice [11,21]. The cumulative effects of direct and indirect toxicity of Aroclor 1254 have affected the nuclear regions of the tubules cells more severely causing tubular necrosis and atrophy [22-24]. Therefore, the overall results of the present study, where the most severe effects were observed after longer exposure durations, were possibly indicative of both direct and indirect toxic effect of Aroclor 1254 to the kidney tissue of mice.

\section{CONCLUSIONS}

Overall, results of the present study suggested a predominantly exposure duration-dependent histopathological effects of the Aroclor 1254 in the mice kidney. In both the doses, most severe effects were observed after longest exposure duration, which were marked by the formation of a large vacuole due to cytoplasmic degradation, and necrosis in most of the Bowman's capsule and the tubular cells. The observed histopathological changes were possibly by both direct and indirect organ-specific effects of the PCB in in vivo conditions. The results suggested that even subacute exposure to very low concentration of PCBs (Aroclor 1254) can lead to irreparable damages to the kidney tissue of mice.

\section{ACKNOWLEDGMENTS}

Authors are thankful to UGC, Government of India, New Delhi, for supporting this study through its CAS programme of the Department of Biosciences, Saurashtra University, Rajkot, India. The authors declare that they have no conflicts of interest.

\section{REFERENCES}

1. Breivik K, Sweetman A, Pacyna JM, Jones KC. Towards a global historical emission inventory for selected PCB congeners a mass balance approach 2. Emissions. Sci Total Environ 2002;290:199-224.

2. Schecter A, Colacino J, Haffner D, Patel K, Opel M, Päpke O, et al. Perfluorinated compounds, polychlorinated biphenyls, and organochlorine pesticide contamination in composite food samples from Dallas, Texas, USA. Environ Health Perspect 2010;118:796-802.

3. Wright DA, Welbourn P. Environmental Toxicology. Cambridge: Cambridge University Press; 2002. p. 70.

4. ATSDR (Agency for Toxic Substances and Disease Registry). Toxicological Profile for Polychlorinated Biphenyls. Draft for Public Comment (Update). Prepared by Research Triangle Institute. Atlanta: Under Contract No. 205-93-0606 for ATSDR, Public Health Service, U.S. Department of Health and Human Services; 1995.

5. Singhal PC, Sharma P, Sanwal V, Prassad A, Kapasi A, Ranjan R, et al. Morphine modulates proliferation of kidney fibroblasts. Kid Int 1998;53:350-7.

6. Bruckner JV, Khanna KL, Cornish HH. Biological responses of the rat to polychlorinated biphenyls. Toxicol Appl Pharmacol 1973; 24:434-48.

7. Vos JG, Beems RB. Dermal toxicity studies of technical polychlorinated biphenyls and fractions thereof in rabbits. Toxicol Appl Pharmacol 1971;19:617-33.

8. Keplinger ML, Fancher OE, Calandra JC. Toxicological studies with polychlorinated biphenyls. Toxicol Appl Pharmacol 1971;19:402.

9. Garthoff LH, Friedman L, Farber TM, Locke KK, Sobotka TJ, Green S, et al. Biochemical and cytogenetic effects in rats caused by short-term ingestion of aroclor 1254 or firemaster BP6. J Toxicol Environ Health 1977;3:769-96.

10. Michael JD. The Toxicologist's Pocket Handbook. $2^{\text {nd }}$ ed. Informa Healthcare USA, Inc., 2008; 44.

11. Confer AW, Panciera RJ. Thomson Special Veterinary Pathology. Vol. 39. St Louis, New York: Mosby; 1995. p. 597-603.

12. Bergman A, Bergstrand A, Bignert A. Renal lesions in baltic grey seals (Halichoerus grypus) and ringed seals (Phoca hispida Botnica). Ambio 2001;30:397-409.

13. Braathen M, Derocher AE, Wiig Ø, Sørmo EG, Lie E, Skaare JU, et al. Relationships between PCBs and thyroid hormones and 
retinol in female and male polar bears. Environ Health Perspect 2004; 112:826-33.

14. Churg J, Bernstein J, Glassock RJ. Renal diseases. In: Classification and Atlas of Glomerular Diseases. New York: Igaku-Shoin; 1995.

15. Hori S, Obana H, Kashimoto T, Otake T, Nishimura H, Ikegami N, et al. Effect of polychlorinated biphenyls and polychlorinated quaterphenyls in cynomolgus monkey (Macaca fascicularis). Toxicology 1982;24:123-39.

16. Sonne C, Leifsson PS, Dietz R, Kirkegaard M, Moller P, Jensen AL, et al. Greenland sledge dogs (Canis familiaris) exhibit liver lesions when exposed to low-dose dietary organ halogen contaminated mink whale (Balaenoptera acutorostrata) blubber. Env Res 2008a; $106: 72-80$.

17. Sonne C, Wolkers H, Leifsson PS, Jenssen BM, Fuglei E, Ahlstrøm O, et al. Organochlorine-induced histopathology in kidney and liver tissue from arctic fox (Vulpes lagopus). Chemosphere 2008; 71:1214-24

18. Koponen K, Myers MS, Ritola O, Huuskonen SE, LindströmSeppä P. Histopathology of feral fish from a PCB-contaminated freshwater lake. Ambio 2001;30:122-6.

19. Lie E, Larsen HJ, Larsen S, Johansen GM, Derocher AE, Lunn NJ, et al. Does high organochlorine (OC) exposure impair the resistance to infection in polar bears (Ursus maritimus)? Part I: Effect of OCs on the humoral immunity. J Toxicol Environ Health A 2004;67:555-82.
20. Lie E, Larsen HJ, Larsen S, Johansen GM, Derocher AE, Lunn NJ, et al. Does high organochlorine (OC) exposure impair the resistance to infection in polar bears (Ursus maritimus)? Part II: Possible effect of OCs on mitogen and antigen-induced lymphocyte proliferation. J Toxicol Environ Health A 2005;68:457-84.

21. Maxie MG. Pathology of Domestic Animals. San Diego: Academic Press; 1993.

22. Kandaswamy S, Senthamilselvan B, Sekaran S, Firdous AB, GunasekaranK, JagadeesanA.Effect ofquercetin haematobiochemical and histological changes in the liver of polychlorinated biphenylsinduced adult male wister rats. J Biomarkers 2013;2013:1-12.

23. Bavithra S, Selvakumar K, Pratheepa KR. Krishnamoorthy G, Venkataraman P, Arunakaran J. Polychlorinated biphenyl (PCBs)induced oxidative stress plays a critical role on cerebellar dopaminergic receptor expression: Ameliorative role of quercetin. Neuro Res 2012;21:149-59.

24. Allen RG, Tresini M. Oxidative stress and gene regulation. Free Radic Biol Med 2000;28:463-99.

\section{How to cite this article:}

Raja J, Pathak S, Kundu R. Low dose and subchronic Aroclor 1254

induced histopathological changes in mice kidney. J App Biol Biotech.

2019;7(03):59-62. DOI: 10.7324/JABB.2019.70311 